\title{
ВИБІР СТАБІЛІЗАТОРА ЕКСТЕМПОРАЛЬНОЇ СУСПЕНЗІЇ З ВІСМУТУ НІТРАТОМ ОСНОВНИМ
}

\author{
Г. М. Мельник, Т. Г. Ярних, Г. Б. Юр'єва \\ Національний фрармацевтичний університет мОз України, Харків \\ yurieva.anyuta@gmail.com
}

ІНФОРМАЦІЯ

Надійшла до редакції / Received: 18.03.2021

Після доопрацювання / Revised: 24.03.2021

Прийнято до друку / Accepted: 29.03.2021

\section{Ключові слова:}

суспензія;

технологія,

стабілізатор;

дослідження.
АНОТАЦІЯ

Мета роботи. Вибір стабілізатора екстемпоральної суспензії з вісмуту нітратом основним із наступним створенням лікарського засобу для застосування в гастроентерології.

Матеріали і методи. Об'єктом дослідження слугували зразки екстемпоральної суспензії з вісмуту нітратом основним, які виготовленні за традиційними правилами приготування суспензій. Дослідження седиментаційної стабільності та ресуспендованості вивчали для зразків суспензії з використанням різних стабілізаторів. Мікроскопічний аналіз проводили для визначення розміру часток та однорідності розподілу дисперсної фрази.

Результати й обговорення. Результати досліджень свідчать, що зразки нестабілізованої суспензії та суспензії з додаванням натрію альгінату, NаКМЦ та ксантанової камеді при зберіганні погіршують свою ресуспендованість і характеризуються агрегативною нестійкістю після 14 діб зберігання. Зразок суспензії 3 аеросилом належить до легкоресуспендованих суспензій і має задовільні характеристики однорідності розподілу часток активного фрармацевтичного інгредієнта в дисперсійному середовищі.

Висновки. Досліджено агрегативну стійкість та зовнішній вигляд зразків суспензії залежно від стабілізаторів та терміну їхнього зберігання. Проведено вивчення ресуспендованості стабілізованих зразків суспензії та обрано аеросил як стабілізатор суспензії з вісмуту нітратом основним для подальших досліджень із розробки екстемпорального лікарського засобу.
Вступ. У медичній практиці суспензії посідають певне місце серед рідких екстемпоральних лікарських фрорм. Призначення препаратів у вигляді суспензій має ряд переваг перед іншими лікарськими формами. Саме суспензії дають змогу ввести тверді нерозчинні речовини з високим ступенем дисперсності в рідину і цим самим забезпечити швидкий та повний прояв лікувальної дії. При необхідності суспензії також можуть забезпечувати пролонгувальну дію та можливість регулювання її тривалості завдяки зміні розміру часток лікарської речовини. Необхідно зазначити, що саме в суспензії є можливість легко коригувати смак, запах та колір, що поліпшує органолептичні показники якості лікарської фрорми $[1,2]$.

3 іншого боку, суспензія є однією з найнестійкіших лікарських фрорм. Цей фракт може спричинити ускладнення при точному дозуванні активного фрармацевтичного інгредієнта, тим самим змінюючи терапевтичний ефрект [3].

Оскільки головним завданням при розробці складу та технології суспензії є забезпечення певної стійкості, що здійснюється за рахунок стабілізаторів та по-

ISSN 2312-0967. Фармацевтичний часопис. 2021. № 2 
верхнево-активних речовин (ПАР), то вибір допоміжних речовин вважається першим етапом. Другим етапом є скринінг агрегативної та седиментаційної стійкості суспензії, а також їхньої ресуспендованості.

Відомо, що агрегативна стійкість дисперсних систем може бути різною: одні системи можуть існувати кілька секунд після їхнього утворення, а інші - впродовж тривалого часу. Найнестійкішими за своєю природою є гідрофобні колоїдні системи, для яких характерна слабка взаємодія між частинками дисперсної фрази і дисперсійним середовищем [4, 5]. До фракторів агрегативної стійкості відносять термодинамічні та кінетичні.

Групу термодинамічних фракторів складають:

1. Електростатичний - зумовлений виникненням на поверхні частинок подвійного електричного шару (ПЕШ), який виникає завдяки іонній адсорбції і сприяє утворенню електростатичних сил відштовхування, які зростають при збільшенні потенціалу поверхні частинок (ф-потенціал) i, особливо, електрокінетичного потенціалу (६-потенціал). Сили електростатичного відштовхування між однойменно зарядженими частинками не дають їм наблизитися одна до одної і злипнутися.

2. Адсорбційно-сольватний призводить до зменшення міжфазного натягу при взаємодії частинок дисперсної фрази з середовищем (завдяки адсорбції та сольватації) і зниженню енергії Гіббса поверхні розподілу фраз; забезпечують введення в суспензії ПАР.

3. Ентропійний $-€$ доповненням до двох перших фракторів і діє у високодисперсних системах, частинки дисперсної фрази яких беруть участь у броунівському русі. Суть його полягає в «прагненні» дисперсної фрази рівномірно розподілитися по всьому об'єму системи [6, 7].

Кінетичні фрактори стійкості знижують швидкість агрегації частинок дисперсної фрази. До них належать:

1) структурно-механічний - пов'язаний з утворенням на поверхні частинок захисних шарів (плівок), які мають пружність та механічну міцність, їх руйнування вимагає затрат енергії та часу; даний фрактор може утворитися і при адсорбції на поверхні;

2) гідродинамічний - призводить до зниження швидкості агрегації внаслідок зміни в'язкості середовища, густини дисперсної фрази та дисперсійного середовища [8-10].

У реальних системах агрегативну стійкість визначають одночасною дією кількох фракторів. Особливо велику стійкість дисперсних систем спостерігають при сукупній дії термодинамічних і кінетичних фракторів, коли поряд зі зниженням міжфазного натягу проявляються структурно-механічні властивості міжфазних прошарків [9].

Мета роботи - вибір стабілізатора екстемпоральної суспензії з вісмуту нітратом основним із наступ-
Фармацевтична технологія, біофармація, гомеопатія

Pharmaceutical technology, biopharmacy, homeopathy

ним створенням лікарського засобу для застосування в гастроентерології.

Матеріали і методи. Об'єктом дослідження слугували зразки екстемпоральної суспензії з вісмуту нітратом основним, які виготовлені за традиційними правилами приготування суспензій. Дослідження седиментаційної стабільності та ресуспендованості вивчали для зразків суспензії з використанням різних стабілізаторів. Мікроскопічний аналіз проводили для визначення розміру часток та однорідності розподілу дисперсної фази.

Результати й обговорення. Екстемпоральну суспензію з вісмуту нітратом основним за класичним прописом традиційно готують дисперсійним методом із використанням прийому скаламучування [1]. Основним недоліком даної технології є седиментаційна та агрегативна нестійкість суспензії. Візуально спостерігається швидке осідання часток дисперсної фрази та утворення міцного шару осаду. Ці явища впливають на точність дозування лікарського засобу та, як наслідок, на фрармакологічну ефективність.

Для виготовлення зразків водних суспензій із вісмуту нітратом основним ми використовували найбільш поширені у фрармацевтичній промисловості стабілізатори: натрію альгінат, натрій карбоксиметилцелюлозу (NaКМЦ), ксантанову камедь та аеросил у різних концентраціях. Концентрацію загусників підбирали на основі літературних даних [11, 12]. Розчини натрію альгінату, натрій-КМЦ та ксантанової камеді готували окремо в різних концентраціях і додавали до суспензії з масовою часткою вісмуту нітрату основного $1 \%$.

Агрегативну стійкість запропонованих зразків суспензій зі стабілізаторами визначали за відомою методикою: в циліндри з притертим корком наливали по $50 \mathrm{~cm}^{3}$ суспензії. Після чого циліндри щільно закривали корком і ретельно перемішували їхній вміст впродовж 5 хвилин (механічним шляхом). Потім циліндри виставляли в ряд і залишали у спокої. Через певні інтервали часу (t) вимірювали об'єми (V) седиментаційних осадів до тих пір, поки вони не переставали змінюватися [4]. За одержаними експериментальними даними побудували діаграми (рис. 1), які давали можливість наочно порівняти агрегативну стійкість стабілізованих суспензій впродовж трьох діб.

На підставі попередньо проведених дослідів для подальшого детального дослідження стійкості обирали стабілізатори в концентраціях, які забезпечували найбільшу стабільність зразків суспензії, а саме: натрію альгінат - 1,5 \%, NaКМЦ - 1,5\%, ксантанова камедь - 2 \%, аеросил - 1 \%. Для побудови кінетичних кривих седиментації $\mathrm{V}=\mathrm{f}(\mathrm{t})$ брали середні значення п'яти вимірювань агрегативної стійкості стабілізованих суспензій (рис. 2).

За даними рисунка 2, зразки суспензії, що були стабілізовані розчином ксантанової камеді та аероси-

ISSN 2312-0967. Pharmaceutical review. 2021. № 2 
Фармацевтична технологія, біофармація, гомеопатія

Pharmaceutical technology, biopharmacy, homeopathy

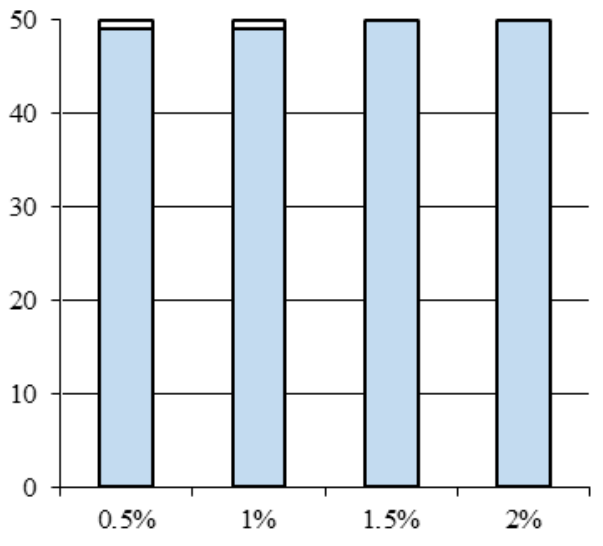

a

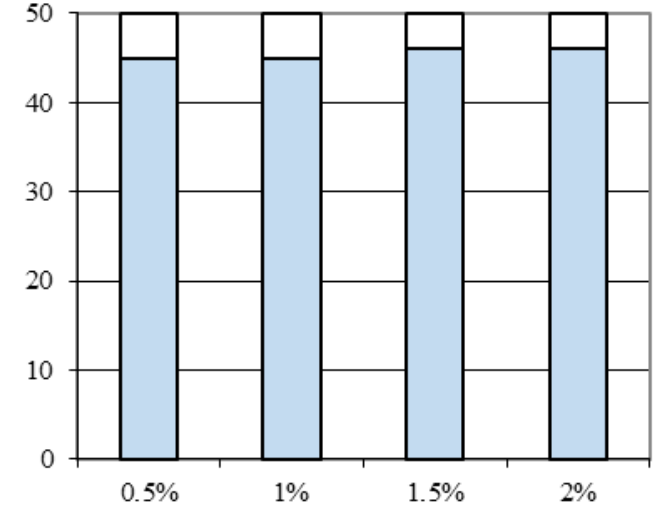

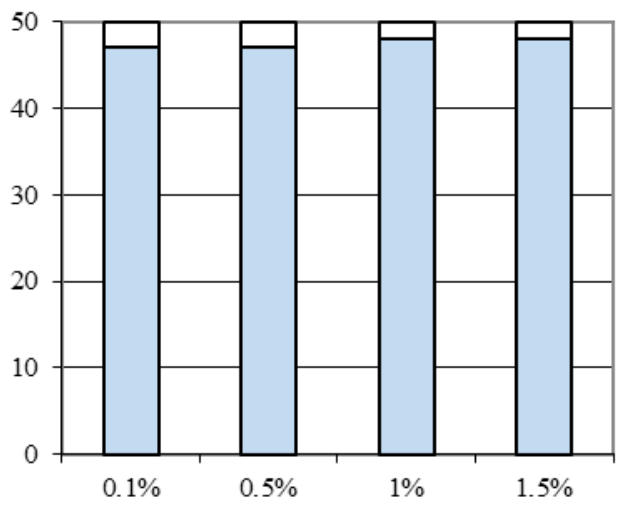

б

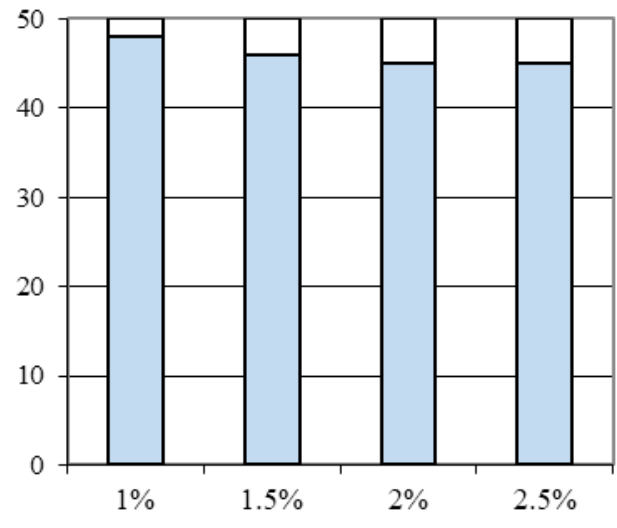

Г

Рис. 1. Стійкість суспензії вісмуту нітрату основного, стабілізованої натрієм альгінатом (а), NаКМЦ (б), ксантановою камедю (в) та аеросилом (г) через 3 доби (по осі абцис - концентрація розчинів стабілізаторів, $\omega$ (\%); по осі ординат - об'єм осаду, см³).

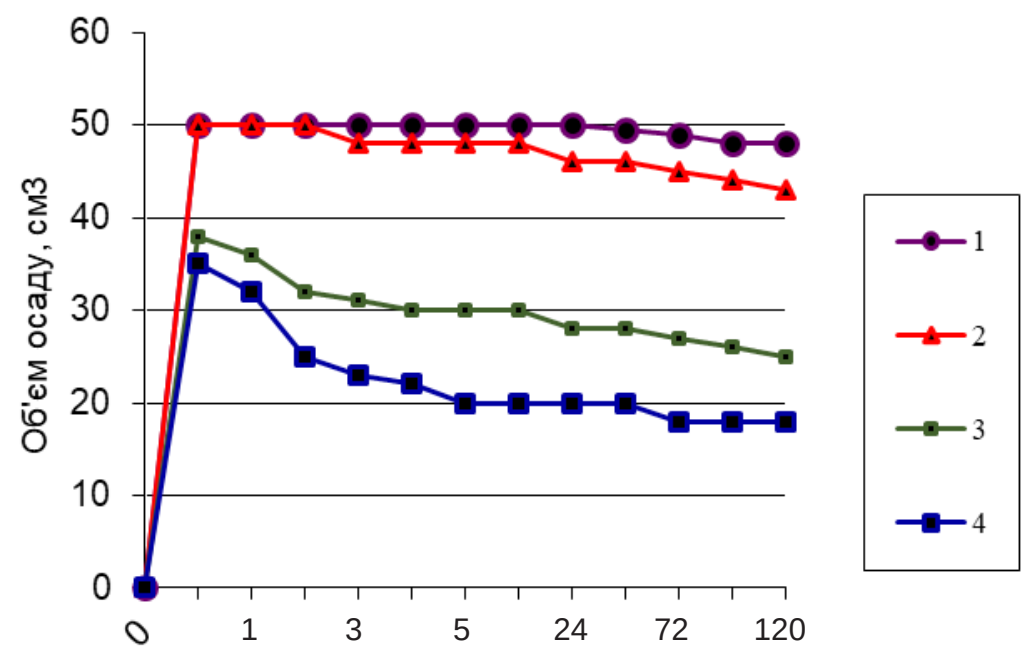

Час, год

Рис. 2. Кінетичні криві седиментації зразків суспензії з вісмуту нітратом основним зі стабілізаторами: 1 - натрію альгінат; 2 - NаКМЦ; 3 - ксантанова камедь; 4 - аеросил.

ISSN 2312-0967. Фармацевтичний часопис. 2021. № 2 
лу, впродовж доби утворювали осади об'ємом до $38 \mathrm{~cm}^{3}$. У суспензіях, стабілізованих натрієм альгінатом та NаКМЦ, спостерігали незначні зміни в об'ємі суспензії лише через 3 доби - 48 та 43 см³ відповідно.

При подальшому зберіганні у зразках, стабілізованих натрієм альгінатом, NaКМЦ та ксантановою камеддю, впродовж 14 діб спостерігали руйнування системи з утворенням білого пластівчастого осаду або щільної гелевої маси (табл. 1).

Для повної оцінки стабільності розроблених зразків суспензії ми також вивчали їхню ресуспендованість.

Ресуспендованість - це здатність суспензії з осадом після легкого струшування утворювати систему 3 твердою дисперсною фазою, рівномірно розподіленою в усьому об'ємі дисперсійного середовища. Ресуспендованість визначає міру оборотності змін у ступені диспергування твердої фрази в рідині, що відбуваються в суспензії впродовж зберігання. В добре ресуспендованій суспензії тверда фраза легко повертається до вихідного стану, тоді як у нересуспендованій суспензії необоротні зміни не дають можливості знову розподілити тверду фразу рівномірно в усьому об'ємі рідини.

Для суспензій ресуспендованість $€$ важливою характеристикою, що визначає поряд 3 агрегативною стійкістю можливість її вірного дозування. Якщо у суспензії впродовж терміну зберігання утворюється погано ресуспендований осад, то таку суспензію не можна виготовляти.

Традиційно показник ресуспендованості суспензій прийнято оцінювати за методикою, згідно з якою визначають кількість струшувань фрлакона із суспензією, яка необхідна для приведення її в вихідний стан із рівномірно розподіленою твердою дисперсною фазою (струшування проводять вручну). Хоча цей метод не є кількісним для визначення міцності осаду, але його найчастіше використовують у фрармацевтичній практиці, оскільки достатньо характеризує придатність суспензій для використання як готовий лікарський засіб.
Фармацевтична технологія, біофармація, гомеопатія Pharmaceutical technology, biopharmacy, homeopathy

Для зручності класифрікації суспензій за здатністю до ресуспендованості та порівняння їх за цим параметром усі суспензії умовно розділяють на чотири групи:

- до першої групи віднесені легкоресуспендовані суспензії, здатні легко повертатися в початковий стан із рівномірним розподілом твердої фрази (менше 5 струшувань);

- до другої групи суспензії з кількістю струшувань від 6 до 10;

- до третьої групи - від 11 до 200 струшувань;

- д до четвертої групи - суспензії, що практично нересуспендуються (більше 200 струшувань) $[4,13]$.

У фрармацевтичній практиці можна використовувати тільки суспензії 1-ї та 2-ї груп; суспензії 3-ї та 4-ї групи мають недостатню здатність до ресуспендованості, тому вони не придатні до практичного застосування.

Кількість струшувань, необхідну для ресуспендованості суспензій після різного терміну зберігання, визначали у суспензіях із масовою часткою вісмуту нітрату основного 1 \% без стабілізатора (прийом скаламучення) та з додаванням допоміжних речовин.

Результати дослідження наведено у таблиці 2.

Як видно з експериментальних даних, зразки нестабілізованої суспензії та суспензії з додаванням натрію альгінату, NaКМЦ та ксантанової камеді при зберіганні погіршують свою ресуспендованість. Це свідчить про те, що утворений осад поступово зміцнюється внаслідок утворення щільної структури.

3 огляду на дані таблиці до легкоресуспендованих суспензій можна віднести зразок суспензії стабілізований аеросилом.

Отже, на основі проведених досліджень як стабілізатор екстемпоральної суспензії обрано аеросил.

3 метою визначення однорідності розподілу активного фрармацевтичного інгредієнта в дисперсійному середовищі ми провели дослідження 3 визначення розміру часток суспензії стабілізованої аеросилом порівняно з суспензією, виготовленою за традиційною технологію (метод скаламучення) (рис. 3).

Таблиця 1

Зовнішній вигляд стабілізованих зразків суспензії з вісмуту нітратом основним у процесі зберігання

\begin{tabular}{|c|c|c|c|c|}
\hline \multirow{2}{*}{ Стабілізатор } & \multicolumn{4}{|c|}{ Термін спостереження, доби } \\
\hline & 1 & 7 & 14 & 30 \\
\hline $\begin{array}{l}\text { Натрію } \\
\text { альгінат }\end{array}$ & $\begin{array}{l}\text { Однорідна після } \\
\text { збовтування }\end{array}$ & $\begin{array}{l}\text { Однорідна після } \\
\text { збовтування }\end{array}$ & $\begin{array}{l}\text { Утворення білого } \\
\text { пластівчастого осаду }\end{array}$ & $\begin{array}{l}\text { Утворення білого } \\
\text { пластівчастого осаду }\end{array}$ \\
\hline NaKMЦ & $\begin{array}{l}\text { Однорідна після } \\
\text { збовтування }\end{array}$ & $\begin{array}{l}\text { Однорідна після } \\
\text { збовтування }\end{array}$ & $\begin{array}{l}\text { Утворення щільного } \\
\text { гелевого осаду }\end{array}$ & $\begin{array}{l}\text { Утворення щільного } \\
\text { гелевого осаду }\end{array}$ \\
\hline Ксантанова камедь & $\begin{array}{l}\text { Однорідна після } \\
\text { збовтування }\end{array}$ & $\begin{array}{l}\text { Однорідна після } \\
\text { збовтування }\end{array}$ & $\begin{array}{l}\text { Утворення щільного } \\
\text { гелевого осаду }\end{array}$ & $\begin{array}{l}\text { Утворення щільного } \\
\text { гелевого осаду }\end{array}$ \\
\hline Аеросил & $\begin{array}{l}\text { Однорідна після } \\
\text { збовтування }\end{array}$ & $\begin{array}{l}\text { Однорідна після } \\
\text { збовтування }\end{array}$ & $\begin{array}{l}\text { Однорідна після } \\
\text { збовтування }\end{array}$ & $\begin{array}{l}\text { Однорідна після } \\
\text { збовтування }\end{array}$ \\
\hline
\end{tabular}

ISSN 2312-0967. Pharmaceutical review. 2021. № 2 
Фармацевтична технологія, біофармація, гомеопатія Pharmaceutical technology, biopharmacy, homeopathy

\section{Таблиця 2}

Порівняльна характеристика ресуспендованості досліджуваних зразків суспензії з вісмуту нітратом основним

\begin{tabular}{|c|c|c|c|c|c|c|c|c|c|c|}
\hline \multirow{2}{*}{$\begin{array}{c}\text { Об'єкт } \\
\text { дослідження }\end{array}$} & \multirow{2}{*}{$\begin{array}{c}\text { Концентрація } \\
\text { стабілізатора } \\
\text { (w), \% }\end{array}$} & \multicolumn{9}{|c|}{ Термін зберігання, доби } \\
\hline & & 1 & 2 & 3 & 4 & 5 & 6 & 7 & 14 & 30 \\
\hline $\begin{array}{l}\text { Суспензія без стабілізатора } \\
\text { (прийом скаламучення) }\end{array}$ & - & 1 & 2 & 3 & 3 & 3 & 3 & 3 & 3 & 3 \\
\hline Суспензія з натрію альгінатом & $1,5 \%$ & 1 & 2 & 2 & 2 & 2 & 2 & 2 & 3 & 3 \\
\hline Суспензія з NаКМЦ & $1,5 \%$ & 1 & 1 & 1 & 2 & 2 & 2 & 2 & 3 & 3 \\
\hline $\begin{array}{l}\text { Суспензія з ксантановою } \\
\text { камеддю }\end{array}$ & $2 \%$ & 1 & 1 & 1 & 1 & 1 & 1 & 2 & 3 & 3 \\
\hline Суспензія з аеросилом & $1 \%$ & 1 & 1 & 1 & 1 & 1 & 1 & 1 & 1 & 1 \\
\hline
\end{tabular}

*Примітка: 1 - перша група; 2 - друга група; 3 - третя група.

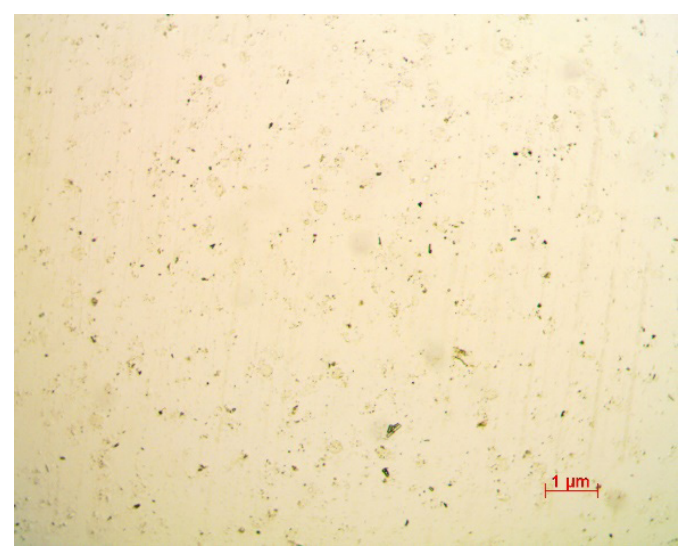

1

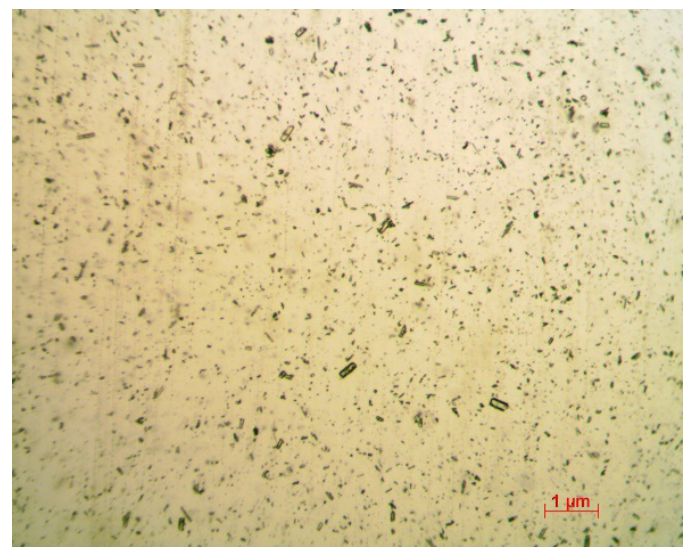

2

Рис. 3. Мікроскопічний аналіз зразків суспензії: 1 - суспензія без додавання стабілізатора; 2 - суспензія стабілізована аеросилом.

За результатами мікроскопічного аналізу можна зробити висновок, що зразок суспензії стабілізованої аеросилом (зразок 2) мав вищий ступінь дисперсності (<1 мкм) порівняно зі зразком 1, що свідчило про однорідність розподілу часток дисперсної фрази в дисперсійному середовищі.

Висновки. 1. Вивчено агрегативну стійкість та зовнішній вигляд зразків суспензії залежно від стабілізаторів і терміну їхнього зберігання.
2. Проведено вивчення ресуспендованості стабілізованих зразків суспензії та обрано аеросил як стабілізатор суспензії з вісмуту нітратом основним для подальших досліджень із розробки екстемпорального лікарського засобу.

Конфлікт інтересів: відсутній.

Conflicts of interest: authors have no conflict of interest to declare. 


\title{
THE CHOICE OF STABILIZER OF EXTEMPORANEOUS SUSPENSION WITH BISMUTH NITRATE BASIC
}

\author{
G. M. Melnyk, T. G. Yarnykh, G. B. Yuryeva \\ National University of Pharmacy of the Ministry of Health of Ukraine, Kharkiv \\ yurieva.anyuta@gmail.com
}

The aim of the work. The choice of stabilizer of extemporaneous suspension with bismuth nitrate basic, followed by the creation of a drug for use in gastroenterology.

Materials and Methods. The object of the study were samples of extemporal suspension of bismuth nitrate basic made according to traditional rules of preparation of suspensions. Sedimentation stability and resuspendability studies were studied for suspension samples using different stabilizers. Microscopic analysis was performed to determine the particle size and homogeneity of the dispersed phase distribution.

Results and Discussion. The results of the study show that samples of nonstabilized suspension and suspension with the adding of sodium alginate, NaCMC and xanthan gum during storage worsen their resuspension and are characterized by aggregative instability after 14 days of storage. The suspension sample with aerosil is a readily suspended and has satisfactory uniformity characteristics of the active pharmaceutical ingredient particles in the dispersion medium.

Conclusions. The aggregative stability and appearance of suspension samples depending on stabilizers and their shelf life have been studied. A study of the resuspension of stabilized suspension samples was performed and aerosil was selected as a stabilizer of suspension with bismuth nitrate basic for a further research on the development of extemporaneous drug.

Key words: suspension; technology, stabilizer; research

\section{ВЫБОР СТАБИЛИЗАТОРА ЭКСТЕМПОРАЛЬНОЙ СУСПЕНЗИИ С ВИСМУТОМ НИТРАТОМ ОСНОВНЫМ}

\author{
Г. Н. Мельник, Т. Г. Ярных, А. Б. Юрьева \\ Национальный фрармацевтический университет МОЗ Украины, Харьков \\ yurieva.anyuta@gmail.com
}

Цель роботы. Выбор стабилизатора экстемпоральной суспензии с висмутом нитратом основным с последующим созданием лекарственного средства для применения в гастроэнтерологии.

Материалы и методы. Объектом исследования послужили образцы экстемпоральной суспензии с висмутом нитратом основным, изготовленные согласно традиционным правилам приготовления суспензий. Исследование седиментационной стабильности и ресуспендируемости изучали для образцов суспензии с использованием различных стабилизаторов. Микроскопический анализ проводили для определения размера частиц и однородности распределения дисперсной фразы.

Результаты и обсуждение. Результаты проведенных исследований показывают, что образцы нестабилизированной суспензии и суспензии с добавлением натрия альгината, NаКМЦ и ксантановой камеди при хранении ухудшали свою ресуспендируемость и характеризовались агрегативной неустойчивостью после 14 суток хранения. Образец суспензии с аэросилом относится к легкоресуспендируемым суспензиям и имеет удовлетворительные характеристики однородности распределения частиц активного фармацевтического ингредиента в дисперсионной среде.

Выводы. Исследовано агрегативную устойчивость и внешний вид образцов суспензии в зависимости от стабилизаторов и срока их хранения. Изучена ресуспендируемость стабилизированных образцов суспензии и выбран аэросил в качестве стабилизатора суспензии с висмутом нитратом основным для дальнейших исследований по разработке экстемпорального лекарственного средства.

Ключевые слова: суспензия; технология; стабилизатор; исследования.

\section{Список бібліографічних посилань}

1. Тихонов О. І., Ярних Т. Г. Аптечна технологія ліків : підруч. для студ. фрармац. фр-ів ВМН3 України III-IV рівнів акредитації / за ред. О. І. Тихонова. вид. 4-те, випр. і допов. Вінниця : Нова Книга, 2016. 536 с.
2. Біофрармація: підручник для студ. фрармац. вищ. навч. закл. і фр-тів. / Тихонов О. І. та ін. ; за ред. О. І. Тихонова. Харків : Вид-во НФаУ; Золоті сторінки, 2003. 240 с.

ISSN 2312-0967. Pharmaceutical review. 2021. № 2 


\section{Analysis of drugs}

3. Yarnykh T. G., Tykhonov O. I., Melnyk G. M., Yuryeva G. B. Pharmacopoeian aspects of suspensions preparation in pharmacy conditions. Asian Journal of Pharma-ceutics. 2017. Vol. 11 (4). P. 859-864.

4. Езерский М. Л., Тенцова А. И., Перькова Н. Н. Физическая устойчивость суспензий некоторых сульсраниламидов. Хим.-фрармац. журн. 1981. № 3. C. $75-81$.

5. Бондаренко А. И. Теоретическое обоснование и практические принципы приготовления фрармацевтических растворов и суспензий : дисс. ... д-ра фрармац. наук. Минск. 1991. 400 с.

6. Liang Y., Hilal N., Langston P., Starov V. Interaction forces between colloidal particles in liquid: Theory and experiment. Adv. in Colloid and Interface Sci. 2007. Vol. 134-135(31). P. 151-166.

7. Ребиндер П. А. Поверхностные явления в дисперсных системах. Коллоидная химия:

\section{References}

1. Tykhonov OI, Yarnykh TG. Pharmacy Technology of Drugs. 4th ed. Vinnytsia: Nova Knyha; 2016. Ukrainian.

2. Tykhonov OI., Yarnykh TG., Zupanets IA. Biopharmacy. [Біосрармація: підручник для студ. фрарм. вищ. навч. закл. і фр-тів.] Kharkiv: Zoloti storinky; 2003. Ukrainian.

3. Yarnykh TG, Tykhonov OI, Melnyk GM, Yuryeva GB. Pharmacopoeian aspects of suspensions preparation in pharmacy conditions. Asian Journal of Pharmaceutics. 2017;11(4): 859-64.

4. Ezerskiy ML., Tentsova Al., Perkova NN. [Physical stability of suspensions of some sulfonamides]. Khimfarmats. zhurn. 1981;3: 75-81. Russian.

5. Bondarenko Al. Theoretical justification and practical principles for the preparation of pharmaceutical solutions and suspensions: Doctoral thesis. Minsk; 1991. Russian.

6. Liang Y, Hilal N, Langston P, Starov V. Interaction forces between colloidal particles in liquid: Theory and experiment. Adv. in Colloid and Interface Sci. 2007;134135(31): 151-66.

7. Rebinder PA. Surface phenomena in dispersed systems. Colloidal chemistry. Selected works.
Избранные труды. М. : Наука, 1978. 368 с.

8. Kosmulski M. Chemical properties of material surfaces. New York: Marcel Dekker, 2001. 576 p.

9. Ходаков Г. С. К реологии суспензий. Теоретические основы химической технологии. 2004. Т. 38 (4). C. 456-466.

10. Воюцкий С. С. Курс коллоидной химии. М. : Химия, 1975. 512 c.

11. Допоміжні речовини в технології ліків: вплив на технологічні, споживчі, економічні характеристики і терапевтичну ефрективність / І. М. Перцев та ін. Харків : Золоті сторінки, 2010. 600 с.

12. Rowe R. C., Sheskey P. J., Quinn M. E. Handbook of Pharmaceutical Excipients. 6th ed. London : Pharmaceutical Press, 2009. $900 p$

13. Езерский М. Л., Тенцова А. И., Перькова Н. Н. Ресуспендируемость суспензий сульфаниламидных препаратов. Фармация. 1983. Т. 33 (6). С. 28-32.

[Поверхностные явления в дисперсных системах. Коллоидная химия: Избранные труды] Moscow: Nauka; 1978. Russian.

8. Kosmulski M. Chemical properties of material surfaces. New York: Marcel Dekker; 2001.

9. Khodakov GS. [To the rheology of suspensions]. Teoret osmov khim tekhnol. 2004;38(4): 456-66. Russian.

10. Voyutsky SS. Colloidal chemistry course. [Kypc коллоидной химии] Moscow: Chemistry; 1975. Russian.

11. Pertsev IM, Dmitrievsky DI, Rybachuk VD. Excipients in drug technology: impact on technological, consumer, economic characteristics and therapeutic efficacy. [Допоміжні речовини в технології ліків: вплив на технологічні, споживчі, економічні характеристики і терапевтичну еоективність] Kharkiv: Zoloti storinky; 2010. Ukrainian.

12. Rowe RC, Sheskey PJ, Quinn ME. Handbook of Pharmaceutical Excipients. London: Pharmaceutical Press; 2009.

13. Ezerskiy ML., Tentsova Al., Perkova NN. [Resuspension of suspensions of sulfanilamide preparations]. Farmatsiya. 1983;33(6): 28-32. Russian.

\section{Відомості про авторів}

Мельник Г. М. - канд. фрармац. наук, докторант кафредри технології ліків, Національний фрармацевтичний університет MO3 України, Харків. E-mail: tI@nuph.edu.ua, ORCID 0000-0002-4333-2094.

Ярних Т. Г. - д. фрармац. наук, профресор, завідувачка кафедри технології ліків, Національний фрармацевтичний університет МО3 України, Харків. E-mail: tl@nuph.edu.ua, ORCID 0000-0001-8496-1578.

Юр'єва Г. Б. - канд. фрармац. наук, доцент кафедри технології ліків, Національний фрармацевтичний університет MO3 України, Харків. E-mail: yurieva.anyuta@gmail.com, ORCID 0000-0001-9719-2122.

\section{Information about the authors}

Melnyk G. M. - PhD (Pharmacy), postdoctoral student of the Technology of Drugs Department, National University of Pharmacy of the Ministry of Health of Ukraine, Kharkiv. E-mail: tl@nuph.edu.ua, ORCID 0000-0002-4333-2094.

Yarnykh T. G. - DSc (Pharmacy), Professor, Head of the Technology of Drugs Department, National University of Pharmacy of the Ministry of Health of Ukraine, Kharkiv. E-mail: tl@nuph.edu.ua, ORCID 0000-0001-8496-1578.

Yuryeva G. B. - PhD (Pharmacy), Associate Professor of the Technology of Drugs Department, National University of Pharmacy of the Ministry of Health of Ukraine, Kharkiv. E-mail: t|@nuph.edu.ua, ORCID 0000-0001-9719-2122.

ISSN 2312-0967. Фармацевтичний часопис. 2021. № 2 